\title{
Obitelj i promovirane vrijednosti čimbenika obitelji u čitankama za hrvatski jezik
}

\author{
Mirko Lukaš*, Anamarija Jurinić***
}

\begin{abstract}
Sažetak
Obitelj se definira kao primarna ćelija ljudskoga oblika udruživanja koja ima svoju specifičnu strukturu. Suvremeno društvo njeguje nuklearnu strukturu obitelji, koju čine roditelji i djeca, a tradicionalna obitelj ima proširenu strukturu. Danas se često susrećemo s nepotpunim obiteljima u kojima nedostaje jedan roditelj ili su to obitelji s očuhom ili maćehom. Obiteljska se funkcija snažno zrcali u odgoju djece i prenošenju osobnoga vrijednosnoga sustava. U nastavi se materinskoga jezika pomoću čitanki diseminiraju pojedine vrijednosne kategorije. Cilj je ovoga rada analizom sadržaja upoznati fenomen obitelji kao književni motiv u čitankama za hrvatski jezik, odrediti čestoću pojavljivanja čimbenika obiteljskoga života koji oblikuju različite strukture i njihovu zastupljenost u tekstovima.

Ključne riječi: odgojni utjecaj; nepotpuna obitelj; redefiniranje; slobodne veze; vrijednosti
\end{abstract}

\section{Uvod}

Tradicionalno se fenomen obitelji odnosi na heteroseksualne roditelje u zajednici s djecom, koji je u prošlosti obuhvaćao suživot više generacija pod istim krovom. Utjecajem globalizacije i naglašenijih liberalnih težnji, koje promoviraju nove vrijednosti i načine razumijevanja međuljudskih odnosa, strukturira se suvremena obitelj, pa se nametnuo zahtjev za njezinim redefiniranjem. Nastupilo je razdoblje krize tradicionalne obiteljske institucije vidljivo u porastu stope razvo$\mathrm{da}$, padu stope nataliteta, porastu broja samohranih roditelja i porastu sklapanja drugoga braka. Snažan je i utjecaj ideologije roda uz proklamiranje sloboda u vezi sa spolnim određenjem pojedinca. Postmodernistička shvaćanja pogoduju sklapanju slobodnih veza koje obitelj proglašavaju zastarjelom i konzervativnom

* Izv. prof. dr. sc. Mirko Lukaš, Odsjek za pedagogiju, Filozofski fakultet Sveučilišta Josipa Jurja Strossmayera u Osijeku. Adresa: Lorenza Jägera 9, 31000 Osijek, Hrvatska. ORCID iD: https:// orcid.org/0000-0003-2725-3035. E-adresa: mirkolukas64@gmail.com

** Anamarija Jurinić, mag. educ. philol. angl. Adresa: Pakračka 8, 32010 Vukovar, Hrvatska. ORCID iD: https://orcid.org/0000-0003-1284-3382. E-adresa: anamarija.jurinic@gmail.com 
te onom koja ograničava slobode pojedinaca. $U$ ovom je radu vidljivo nastojanje društva da kurikulumom nastave hrvatskoga jezika proklamira službene stavove nacionalne zajednice o promatranom pojmu uz primjenu načela inkluzije, koje promovira prihvaćanje osoba svih oblika različitosti. Odgojna je uloga škole kritičkom analizom nastavnih sadržaja postojeće oblike zajednica podržavati ili proglasiti nepoželjnima uz argumentiranje tradicionalnih i suvremenih pogleda.

\section{Definiranje fenomena obitelj}

Obitelj je najstarija ljudska institucija, nepresušni izvor i interes različitih rasprava (Juul, 1995). Pojam obitelji (eng. family) proizvod je zapadne civilizacije. Pojedine ga kulture uopće nemaju, a u mnogim se društvima rabi za opis različitih odnosa i prenošenje različitih značenja (Stacey, 1996, 38). Iako pojam obitelji postoji već na prvim stranicama Biblije (Post 1-2) i odnosi se na posljedicu sjedinjenja muža i žene u sakramentu braka, u povijesti ljudskoga roda ženidba i brak javljali su se u različitim oblicima. Najčešći oblik u kojem se javlja obitelj monogamna je zajednica muškarca i žene, ali uz nju se javlja i poligamna obiteljska zajednica, koja može biti poliginijska kao brak jednoga muža s više žena, ili u rjeđim slučajevima poliandrijska kao brak jedne žene s više muškaraca (Benvin, 1972, 35).

Funkcije obitelji sastoje se u zadovoljavanju primarnih i sekundarnih ljudskih potreba u vezi s reprodukcijom, njegom, socijalizacijom i pripremom mladih na spremno suočavanje sa životnom stvarnošću kojoj su izloženi (Nimac, 2010). Ona je određena društvenim i biološkim zakonitostima (Janković, 2008, 7-8). Obitelj je do danas ostala »primarna društvena zajednica « koja ima »vitalne važnosti « za svakoga pojedinca. Ona je »temelj njegova ostvarivanja i uključivanja u širu društvenu zajednicu « te ima ulogu »povijesnog, vjerskog, kulturnog i generacijskog transfera « (Nimac, 2010, 26). Brak i obitelj mjesto su sigurnosti i potrebnoga međusobnoga prihvaćanja, gdje se pojedinac osjeća slobodnim bez ograničenja u vlastitom djelovanju. Nasuprot tomu, društvo iskazuje trajnu težnju preuzimanja pojedinih obiteljskih zadaća, ali obitelj za sada ostaje stabilna i nikada neće moći biti u potpunosti zamijenjena, niti joj se može pronaći bliska alternativa (Mijatović, 1995).

Rezultat promjena koje su utjecale na obiteljsku instituciju dovele su do toga da možemo govoriti o taksonomiji obitelji, koja obuhvaća sljedeće dimenzije: »biološku povezanost, bračni status, seksualnu orijentaciju, roditeljsku ulogu i status zaposlenosti« (Harway1996, 9 prema Rosić i Zloković, 2002, 16). Američki znanstvenici upućuju na činjenicu da obitelj postaje »ugrožena vrsta«, jer dolazi do pojave raspadanja obiteljskih zajednica i njihova restrukturiranja (RabotegŠrić, 2001, 221). Williams Bowlby tradicionalnu obitelj »definira kao osnovnu stanicu i model društvenog poretka. [...] ona je primarna društvena zajednica koja se izdvaja iz drugih društvenih grupa time što članovi u njoj žive čitav život ili duži period svoga života« (Mijatović, 1995, 468). 
Od velikoga broja utjecaja na transformaciju obitelji u hrvatskom kontekstu najbitniji su: »rastuća bračna ranjivost i njezine nove karakteristike«; od »društvenoga čina « brak postaje »osobni poduhvat«; bračni par postaje »norma sam sebi«, što za posljedicu ima poremećaj ravnoteže te utječe na »etičko-normativni aspekt braka «i uzrokuje njegovu nestabilnost. Zatim su tu »pad nataliteta i nova značenja roditeljstva $\ll i$ »produženi ostanak djece $u$ obitelji $\ll$. Uz navedeno postoji i snažan utjecaj »kulture puerocentrizma « u kojoj roditelji svu svoju energiju i trud ulažu u manji broj djece i teško se mire s činjenicom da će ta djeca jednom napustiti dom (Nimac, 2010, 31).

\section{Obitelj iz perspektive suvremenoga čovjeka}

Postmodernistička shvaćanja doprinijela su liberalnijemu pogledu, što za posljedicu ima filozofiju individualizma, očitovanu u slobodi izbora i usredotočenosti na vlastite interese. Rodna ideologija u podjednakoj mjeri utječe na pojavu nejasnih partnerskih i obiteljskih oblika života. Kultura individualizma dokida sposobnost življenja u zajednici, postavljajući osobne interese ispred tuđih. Utrka za karijerom i zahtjevi za požrtvovnošću koje iziskuje obiteljski život dovode do toga da brak gubi privlačnost u očima mladih ljudi, što uzrokuje i sve manji broj sklapanja istih (Maleš, 2012). Krajem 20. stoljeća pojavljuje se termin $f a$ milies of choice, koji se koristi za određivanje alternativnih oblika obiteljskoga života. Struktura tradicionalne obiteljske institucije promijenjena je u pogledu povezivanja roditeljske uloge sa seksualnim ulogama, ali i seksualnom orijentacijom (Švab, 2007). Danas se javlja i termin "više-partnerska plodnost", koji se odnosi na sve koji imaju biološku djecu s više od jednoga partnera, unutar ili izvan bračne zajednice. Porast stope razvoda i preudavanja pridonosi pojavi navedena fenomena. U porastu je i stopa rađanja kod žena koje nisu udane, pa je u Americi rođeno u tim okolnostima sredinom 2000. godine oko $40 \%$ djece (Pew Research Center, 2015).

Među suvremene modele obitelji navodimo fast-food obitelj i "virtualnu" obitelj. Za fast-food obitelji karakteristični su brojni disfunkcionalni obrasci, kao što su površni i virtualni odnosi, pod čime se podrazumijeva komunikacija SMS porukama, e-poštom i sl. U takvim su obiteljskim modelima marginalizirani osjećaji međusobnoga razumijevanja, žrtva za drugoga i međusobna podrška (Miliša, 2014, 149). Model "virtualne" obitelji prepoznat je od 2003. godine, od kada se život obitelji odvija i na Internetu. U njemu je moguće »virtualno obiteljski živjeti, stanovati, odlaziti u kupovinu, na kino-predstave, imati virtualnog bračnog partnera, imati virtualne intimne odnose, djecu ili roditelje koje smo, kao i sebe sami prethodno kreirali, od boje očiju, kose, stasa, ponašanja, itd.« (Miliša, 2014, 150).

Na razvoj obitelji kao institucije snažan utjecaj danas imaju mediji, koji postaju sukonstruktori stvarnosti u kojoj živimo. Slike idilične obitelji uz koje idu hedonizam i konzumerizam postale su često nametani obrasci koji narušavaju sliku stvarnosti i vode razočarenju (Koračević, 1999). U visokorazvijenim zemljama danas prevladavaju obitelji bez djece ili s tek jednim djetetom, ili djeca bez 
cjelovite obitelji. Razlog su za to novi sustavi vrijednosti, ženina zaposlenost, izgradnja karijere, pa sve do preferiranja egoističke i potrošačke kulture (Aračić i Nikodem, 2000). Možemo se zapitati što je zapravo ostalo od slike starih obitelji? Ostala je briga majke za djecu i ljubav, koja je sve manja jer je majka zaposlena, a ljubav (p)ostaje težnja, želja, nada i sve manje postoji iskustvo ljubavi (Gjergji, 1982, 321). »Kako god je mi definirali, usprkos mnogim supstitutima i surogatima koji se danas pojavljuju i traže pravo priznanja vlastitog statusa, obitelj se pokazuje kao jedinstvena forma zajedničkog života i nosilac presudnih funkcija za životnu zajednicu « (Nimac, 2010, 27).

Totalitarna vlast 20. stoljeća imala je namjeru uništiti obiteljsku zajednicu utemeljenu na ženidbi, ali je Općom deklaracijom o pravima čovjeka iz 1948. godine obranjena i osigurana njezina opstojnost. Člankom 16 spomenute Deklaracije istaknuto je da je »obitelj prirodna i osnovna društvena jedinica i ima pravo na zaštitu društva i države « (Čondić, 2009, 8-9). To da je obitelj od iznimne važnosti svjedoči i činjenica da su Ujedinjeni narodi i Katolička crkva 1994. godinu proglasili Godinom obitelji (Balaband, 1994).

Prosječna europska obitelj ima tri člana, a svaki treći brak završi razvodom. Ekvivalentno tomu, sve je veći broj izvanbračne djece, »najviše na Islandu 63\%, Švedskoj i Estoniji 56\%, a najmanje u Hrvatskoj 9\% i Grčkoj 4\%« (Miliša, 2013).

Novi modeli obitelji postale su jednoroditeljske obitelji, rekombinirane obitelji, homoseksualne obitelji i slobodne veze (Trujillo, 2003). Na pojavu većega broja razvoda brakova utjecali su netradicionalni obiteljski modeli kao što su "vikend-odnosi", "zajednički život” i "civilno partnerstvo (OECD, 2003, 24).

U Americi su sve češće pojave "mješovitih" obitelji, odnosno kućanstva u kojima žive djeca s očuhom, pomajkom, polubraćom i polusestrama (Pew Research Center, 2015). Novija su pojava u američkom društvu i gayby boom, odnosno povećani broj djece u obiteljima homoseksualnih parova. Prema istraživanjima Instituta Williams u Los Angelesu, oko sto tisuća homoseksualnih parova danas odgaja djecu. Na tu je pojavu utjecalo legaliziranje homoseksualnih brakova i težnja da se oni izjednače s brakovima heteroseksualnih parova (Angier, 2013). Čest je oblik življenja u Americi i suživot s ljudima koji uopće ne moraju biti rodbinski povezani, a koji je dosegnuo brojku od oko 6,5 milijuna kućanstava.

\section{Pogled na vrijednosti u odgoju}

Pojam vrijednost dolazi od latinske riječi valeo i ima značenja kao što su "krepak", "jak", "zdrav" i "valjan”. Vrijednost je termin kojim se služimo kako bismo u svakodnevnom govoru označili ono što je dobro, lijepo pravedno i istinito. Ujedno vrijednost predstavlja opći naziv za sadržaj morala, umjetnosti, prava, običaja, politike i drugih formi društvene svijesti (Životić, 1986, 47).

»'Vrijednosti koje njegujemo', 'temeljne obiteljske vrijednosti', 'sustav vrijednosti koje društvo prihvaća i promiče’ — izrazi su koje gotovo redovno susrećemo ili primjenjujemo u svakodnevnom govoru. U medijima čitamo i slušamo o 'pravim vrijednostima', 'nestajanju tradicijskih društvenih vrijednosti', 'vremenu 
novih vrijednosti' [...] Mogli bismo reći da gotovo svatko od nas zna ili barem razumije što su to 'vrijednosti'. Ali se znanstvenicima zadatak jasnog i preciznog određenja pojma ‘vrijednosti’ nipošto nije pokazao lakim« (Ferić, 2009, 11).

»Istraživanja vrijednosti najčešće su u skladu s prevladavajućim orijentacijama i objašnjavane su uvjetima društvenog života pri čemu se najčešće istražuju odnosi između sustava vrijednosti i društvene strukture, ciljeva, potreba, tradicije, slojeva, klasa itd. Najčešće se i implicitno i eksplicitno polazi od pretpostavke da je osnovni smisao vrijednosti u funkcijama socijalizacije pojedinaca i održavanju postojeće društvene organizacije« (Lukaš, 2010, 39).

Postoje razna polazišta i pogledi na teorije vrijednosti koje su najčešće ovisne o znanstvenom području s kojega se promatraju. Ipak, prevladava zajedničko razmišljanje da su vrijednosti, ideje i odnosi pojedincima, skupinama i društvima poželjni, a identifikacija ljudi s vrijednostima osigurava integraciju i održavanje društva (Mrnjaus, 2008, 8-9).

Neophodno je navesti i distinkciju između vrijednosti i vrijednosnih orijentacija. Vrijednosti su poželjne i cijenjene ideje i ciljevi, a vrijednosne orijentacije predstavljaju opća načela ponašanja, djelovanja i življenja i usko su povezana s određenim ciljevima čijemu se ostvarenju teži. Prema navedenoj razlici, vrijednosti bi bile poštenje, dostojanstvo i sloboda, a vrijednosne orijentacije predstavljale bi liberalizam, tradicionalizam, konzervatizam, individualizam i slično (Piršl i Vican, 2004, 92).

Razmatrajući teorijske pristupe u konstituiranju vrijednosti, stvorile su se i razne ideje o njihovu sustavu i hijerarhiji po kojem bi ih bilo moguce rangirati. Konačna hijerarhija vrijednosti danas uopće ne postoji, a pojedini autori ne žele priznati postojanje takve hijerarhije (Hoblaj, 2005, 389). Hijerarhija vrijednosti promatra se kao izraz potreba pojedinca koje su promjenjive. Stoga je i sama hijerarhija relativna i ovisi o određenim prioritetima u izboru kojima pojedinac ovisno o situaciji u kojoj se nalazi daje prednost.

Živan Bezić (1990, 148-150) rangira vrijednosti u obliku skale i prezentira ih u sljedećim vrijednosnim kategorijama: 1. biološke, 2. ekonomske, 3. društvene, 4. estetske, 5. intelektualne, 6. moralne (etičke) i 7. religiozone.

Za razliku od normi koje se krše ili ne, vrijednosti u sebi uvijek podrazumijevaju pozitivne preferencije. Stav može biti negativan ili pozitivan, a vrijednosti su uvijek s većim ili manjim intenzitetom pozitivne preferencije. Ne postoje 'negativne’ vrijednosti (Miliša i Bagarić, 2012, 92-93).

S obzirom na pluralnu narav vrijednosti, osnovni je problem socijalizacije i odgoja u suvremenom društvu »kako u vrijednosnoj socijalizaciji prevladati stanje 'vreće vrlina' i osigurati integraciju vrijednosne strukture ličnosti na načelnoj razini. Kao jedan od preduvjeta rješavanja ovoga problema javlja se integriranje filozofskih i znanstvenih spoznaja o vrijednostima u jedinstvenu teoriju, oslobođenu relativističkih stavova i njeno inkorporiranje u opću teoriju odgoja « (Rafajac, 1991, 38).

Vrijednosti su sastavni dio čovjekova života kao "vrijednosnoga bića” od rođenja pa sve do smrti. Čovjek zauzima vrijednosna stajališta prema svemu što ga 
okružuje, on donosi pozitivne i negativne sudove o ljudima, stvarima i pojavama, prepoznaje u njima dobro i zlo, humano i nehumano (Vukasović, 1999). Vrijednosti predstavljaju skup mišljenja, stavova i uvjerenja o tome što je dobro, ispravno ili poželjno, a formiraju se socijalizacijom (Mlinarević, 2014, 125).

»Ne postoji nijedna skupina koja bi se odrekla prenošenja specifičnih vrijednosti i normi na svoje potomke. Samo ona skupina koja se raspada i koja je ravnodušna prema svojoj budućnosti dopušta da njezino potomstvo raste bez odgoja za vrijednosti« (Brezinka prema Mrnjaus, 2008, 21).

Vrijednosti su neophodne u odgoju jer služe za određivanje odgojnih ideala, ciljeva, svrha i zadaća odgajanja. Odgojne vrijednosti mogu se promatrati s pozicija cilja ili sredstva odgoja. Usvajanje vrijednosti predstavlja ujedno i svrhu odgoja, ali u isto vrijeme i sredstvo jer se cijeli odgoj vodi pomoću vrijednosti i vodi prema njima (Munjiza et al., 2007, 209).

Smjernica za ono što želimo postići odgojem promatra se kao odgojni ideal koji je »slika savršenog čovjeka, projekcija zbilje, pogled na razvoj čovjeka koji se želi postići odgojem. Odgojni ideal je skup predodžbi o poželjnim odlikama čovjeka neke zajednice « (Mušanović i Lukaš, 2011, 48). U razvoju zapadne civilizacije posebnu važnost ima kršćanski odgojni ideal, koji naglašava duhovne i transcendentne vrijednosti kao važnu odrednicu čovjeka. Suprotno tomu, naturalističko-materijalistički odgojni ideal naglašava odrednicu čovjeka kao prirodnoga i radnoga, odnosno materijalnoga i proizvodnoga bića, da bi danas sve više bio prisutan ideal jednostranoga čovjeka (homo consumens), koji označava čovjeka kao biće potrošnje (Mušanović i Lukaš, 2011, 49).

U ovom radu fokus je na udžbenicima književnosti za obvezno osnovno obrazovanje, odnosno čitankama za hrvatski jezik, čija je primarna namjena poučavanje i učenje književnosti. Kao odgojni sadržaji u čitankama su predočeni različiti tekstovi, priče, pjesme, odlomci iz pripovijetki, bajki i dr. Tim se sadržajima na zanimljiv i poučan način, izravno i neizravno, odgajaju djeca i mladi, a implicitnim porukama prenose se društveno prihvatljive norme i vrijednosti (Božić Lenard i Lenard, 2018, 296).

\section{Metodološki pristup}

U ovom je radu pristupljeno analizi sadržaja tekstova čitanki za nastavu hrvatskoga jezika od 5. do 8. razreda osnovne škole kojom se utvrđuje obitelj kao motiv u odabranim tekstovima i prepoznaju vrijednosti najčešce povezne sa strukturom obitelji i pojedinim njezinim članovima. Za potrebe rada analizirani su tekstovi 12 hrvatskih čitanki namijenjenih za predmetnu nastavu osnovne škole, po četiri iz tri izdavačke kuće: 1. Školska knjiga (Šojat, 2013; 2014a; 2014b; 2014c); 2. Profil (Babić et al., 2005a; 2005b; 2005c; 2005d); 3. Ljevak (Bežen i Jambrec, 2009a; 2009b; 2009c; 2009d).

Analizom sadržaja tekstova čitanki za hrvatski jezik osnovne škole prepoznati su autori čitanki, autori odabranih tekstova u čitankama, motiv obitelji i njezinih članova kao i vrijednosti koje su povezane s njihovom ulogom. U tekstovima koji 
su analizirani pomoću samostalno konstruiranih protokola odabrane su prethodno predviđene istraživačke kategorije na temelju kojih su objedinjeni dobiveni pokazatelji i doneseni su zaključci.

\section{Interpretacija rezultata istraživanja}

Od 12 analiziranih udžbenika za nastavu hrvatskoga jezika od 5. do 8. razreda osnovne škole i 25 autora čitanki $80 \%$ su žene $(\mathrm{N}=20)$ i $20 \%$ su muškarci $(\mathrm{N}=5)$.

Tablica 1. Autori tekstova u čitankama prema spolu Table 1. Authors of texts in readers according to gender

\begin{tabular}{|l|c|c|c|c|}
\hline Autorstvo tekstova & $\check{Z}$ & $M$ & Autor nepoznat & $\Sigma$ \\
\hline Ukupno & 113 & 613 & 56 & 782 \\
\hline
\end{tabular}

Analizom 782 teksta unutar odabranih čitanki dolazimo do pokazatelja da su njihovi autori muškoga spola u $78 \%$ slučajeva $(\mathrm{N}=613)$, a žene su kao autorice tekstova zastupljene u svega $14 \%$ slučajeva $(\mathrm{N}=113)$. U $8 \%$ primjera $(\mathrm{N}=56)$ autor nije naveden, primjerice narodna brojalica iz Kastva Mladi glazbar (Babić et al., 2005d), ili je autor nepoznat, primjerice kratki prozni tekst Učiteljica $i$ učenik (Šojat, 2014a).

Sve čitanke tematski su podijeljene na cjeline i pojedine nastavne jedinice. Motiv obitelji i njezinih čimbenika pojavljuju se i u naslovima cjelina i u naslovima tekstova obuhvaćenih u pojedinim cjelinama u kojima je najčešće spomenut djed u $25 \%$ slučajeva $(\mathrm{N}=14)$. Relativno se često pojavljuju majka $(19,64 \%, \mathrm{~N}$ $=11) \mathrm{i}$ otac $(16,07 \%, \mathrm{~N}=9)$. Učestalost pojavljivanja pojedinih članova obitelji u tekstovima je analizirana na način da je na članove obitelji gledano iz perspektive djeteta, pa je ista ženska osoba u nekom tekstu mogla imati ulogu majke, ulogu supruge, ulogu sestre, ulogu kćeri i sl., no zabilježena je samo kao majka jer ovaj rad istražuje strukturu obitelji, a ne raznolike uloge njezinih članova.

Posredovane vrijednosti majke i oca (Tablica 2) imaju veliku moralnu snagu, kojom se roditelji odupiru svim izazovima koji su pred njih postavljeni tijekom brižnoga i zahtjevnoga odgoja potomaka. Vidljive su zajedničke promovirane vrijednosti ljubavi, hrabrosti, ljepote, ugleda i religioznosti oba roditelja. Samo poštovanjem i promoviranjem navedenih vrijednosti roditelji mogu biti ideal i uzor svojoj djeci, skrbiti za njihov uspjeh i napredak u životu, kako tjelesni tako i duhovi. Zatim je u analiziranim tekstovima majka opisana kao marljiva, nježna, brižna, utočište sigurnosti i socijalno zaštitnička prema svojoj djeci. Od suvremenoga se otca isto tako očekuje osjećajnost, upornost, obrazovanje i marljivost. Što implicira tradicionalan pogled na roditeljsku ulogu otca hranitelja i ekonomskoga staratelja za članove svoje obitelji. 
Tablica 2. Vrijednosti koje promoviraju roditelji u tekstovima čitanki

Table 2. Values promoted by parents in the texts of the readers

\begin{tabular}{|c|c|}
\hline Majka & Otac \\
\hline \multicolumn{2}{|c|}{ Ljubav } \\
\hline \multicolumn{2}{|c|}{ Hrabrost } \\
\hline \multicolumn{2}{|c|}{ Ljepota } \\
\hline \multicolumn{2}{|c|}{ Ugled } \\
\hline \multicolumn{2}{|c|}{ Religioznost } \\
\hline Marljivost & Osjećajnost \\
\hline Nježnost & Obornost \\
\hline Osjećaj sigurnosti & Pažljivost \\
\hline Brižnost & \\
\hline Socijalna osjetljivost & \\
\hline
\end{tabular}

Tablica 3. Vrijednosti pripisane određenomu spolu djeteta

Table 3. Values attributed to the particular sex of a child

\begin{tabular}{|c|c|}
\hline Žensko dijete & Muško dijete \\
\hline & Dobrota \\
\hline & Darovitost \\
\hline \multicolumn{3}{|c|}{ Marljivost } \\
\hline Samostalnost & Hrabrost \\
\hline Ljepota & Skromnost \\
\hline Obrazovanost & Osjećajnost \\
\hline Poslušnost & Spretnost \\
\hline
\end{tabular}

Vrijednosti koje su posredovane pomoću motiva likova djece razlikuju se prema spolu (Tablica 3). Djeca moraju biti dobra i marljiva i na ponos roditeljima iskazujući svoje naslijeđene darovitosti. Za žensku populaciju osnovne škole autori promoviraju vrijednosti poput: samostalnost, ljepota, obrazovanost, poslušnost i razumno ophođenje. Dječaci bi trebali stremiti vrlinama hrabrosti, skromnosti, iskazivanju osjećaja, biti spretni u obavljanju različitih zadaća koje su pred njih postavljene te ne smiju zapostavljati svoje roditelje. Analizom promoviranih vrijednosti kod muškoga spola nismo pronašli veliku razliku od tradicionalnoga pogleda na odgoj dječaka.

Vrijednosti posredovane putem starijih i iskusnih čimbenika obiteljskoga odgoja bake i djeda također se razlikuju, uz marljivost kao zajedničku promoviranu vrijednost, te majčinsku ekstenziju bake te izrazitu pravednost i ekološku mudrost djeda (Tablica 4). 
Tablica 4. Vrijednosti koje promiču bake i djedovi

Table 4. Values promoted by grandparents

\begin{tabular}{|c|c|}
\hline Baka & Djed \\
\hline & Marljivost \\
\hline Religioznost & Ekološka svijest \\
\hline Mudrost & Pravednost \\
\hline Ljubav & \\
\hline Dobrota & \\
\hline Osjećaj sigurnosti & \\
\hline
\end{tabular}

Strukturu obitelji možemo promatrati prema broju generacija koje žive unutar jedne obitelji i njihovoj prisutnosti ili neprisutnosti, kao i promatrajući njihove međusobne odnose. Prihvatimo li kategoriju broja generacija unutar obitelji, tada razlikujemo nuklearnu i proširenu obitelj. U analiziranim čitankama obitelj je izravno spomenuta $(\mathrm{N}=126)$, od toga se nuklearna obitelj pojavljuje češce $(69,05 \%, \mathrm{~N}=87)$ u odnosu na proširenu obitelj $(30,95 \%, \mathrm{~N}=39)$.

Tablica 5. Obiteljske strukture prikazane unutar tekstova čitanki Table 5. Family structures displayed in the texts of the readers

\begin{tabular}{|c|c|c|c|c|c|c|c|c|c|c|c|c|c|}
\hline $\begin{array}{c}\text { Struktura } \\
\text { obitelji }\end{array}$ & $\begin{array}{l}n \\
n \\
-\tilde{u} \\
: 5 \\
0 \\
0 \\
0 \\
5 \\
5\end{array}$ & $\begin{array}{c}0 \\
0 \\
i \tilde{0} \\
: 5 \\
0 \\
0 \\
0 \\
5 \\
5\end{array}$ & 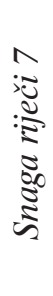 & 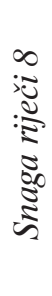 & 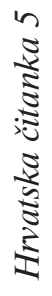 & 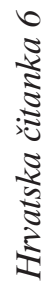 & 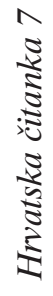 & 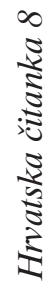 & 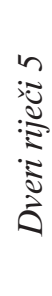 & 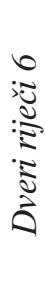 & 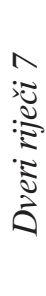 & 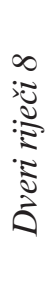 & $\Sigma$ \\
\hline Nuklearna & 14 & 11 & 6 & 10 & 3 & 7 & 10 & 6 & 7 & 6 & 2 & 5 & 87 \\
\hline Proširena & 9 & 3 & 2 & 3 & 3 & 3 & 2 & 4 & 4 & 3 & - & 3 & 39 \\
\hline Ukupno & 23 & 14 & 8 & 13 & 6 & 10 & 12 & 10 & 11 & 9 & 2 & 8 & 126 \\
\hline Potpuna & 10 & 7 & 5 & 9 & 4 & 11 & 9 & 5 & 7 & 9 & 3 & 4 & 83 \\
\hline Nepotpuna & 3 & 10 & 5 & 8 & 3 & 3 & 5 & 2 & 5 & 1 & - & 7 & 52 \\
\hline Adoptirana & 1 & 1 & - & 1 & - & 3 & 1 & - & - & 1 & 1 & - & 9 \\
\hline $\begin{array}{c}\text { Očuh/maćeha u } \\
\text { obitelji }\end{array}$ & - & - & 1 & 1 & - & - & - & - & - & - & - & - & 2 \\
\hline Ukupno & 14 & 18 & 11 & 19 & 7 & 17 & 15 & 7 & 12 & 11 & 4 & 11 & 146 \\
\hline Zapuštena & 2 & 2 & 3 & 1 & - & 3 & 3 & - & - & 1 & - & 2 & 17 \\
\hline
\end{tabular}


Analiziramo li prisutnost ili neprisutnost različitih obiteljskih članova, tada razlikujemo potpunu, nepotpunu i razvedenu obitelj s razdvojenom djecom, adoptirane obitelji, obitelji s očuhom ili maćehom te obitelji s djecom očuha ili maćehe. Od navedenih struktura, u analiziranim čitankama pronađeno je ukupno 146 oblika opisanih struktura, s primjerima potpune, nepotpune, adoptirane obitelji te očuh i maćeha u obitelji. Adoptirane obitelji spomenute su 9 puta $(6,16 \%)$, a obitelji s očuhom i maćehom 2 puta $(1,37 \%)$, što predstavlja izuzetnu rijetkost kada se promatra njihova sve veća prisutnost u svakodnevnom životu našega društva. Nepotpune obitelji prilično su čest motiv analiziranih tekstova $(\mathrm{N}=52,38,52 \%)$, što se može opravdati sve većim javnim istupom o inkluziji osoba svih različitosti, kao i toga što nam to ona svakodnevno donosi. Odgojnost nastave hrvatskoga jezika još je uvijek sklona promovirati potpune obitelji koje imaju dominantno značenje: $\mathrm{N}=83$ ili $61,48 \%$.

Posebna pozornost usmjerena je na tekstove koji ilustriraju situacije zapuštenih obitelji, a koja može biti prisutna i u potpunoj i u nepotpunoj obitelji. Učestalost te čestice izračunata je na temelju ukupnoga broja potpunih i nepotpunih obitelji $(\mathrm{N}=135)$ prema odnosu na spomenutu zapuštenost koja iznosi $\mathrm{N}=$ 17 ili $12,59 \%$. Učestalost pojavljivanja pojedine obiteljske strukture u čitankama vidljiva je u Tablici 5 .

U analiziranim tekstovima najčešće se spominju kao motivi nositelja vrlina i vrijednosti obiteljskoga života članovi nuklearne obitelji. Na prvom mjestu ističemo dijete $(\mathrm{N}=208,28,65 \%)$, zatim majku $(\mathrm{N}=184,25,34 \%)$ i otca $(\mathrm{N}=147$, $20,25 \%$ ). Interesantno je istaknuti kako spomenute obitelji u promatranim tekstovima u gotovo dva puta većem postotku imaju muško dijete $(\mathrm{N}=135,18,6 \%)$, a žensko se dijete spominje u 73 puta $(10,06 \%)$. Povremeno se u tekstovima pojavljuju baka i djed, te brat i sestra, a rjeđe se pojavljuju ujak, stric i strina, tetka te bratić i sestrična (Tablica 6).

Tablica 6. Čimbenici obitelji u tekstovima čitanki prema učestalosti pojavljivanja Table 6. Family factors in the texts of the readers according to frequency of occurrence

\begin{tabular}{|c|c|c|c|c|c|c|c|c|c|c|c|c|c|}
\hline $\begin{array}{c}\text { Čimbenik } \\
\text { obitelji }\end{array}$ & 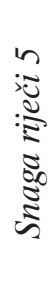 & 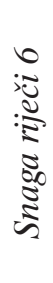 & 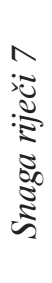 & 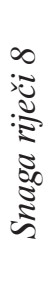 & 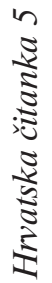 & 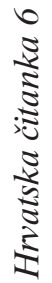 & 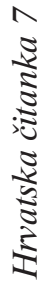 & 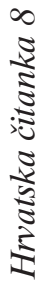 & 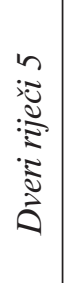 & 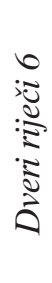 & 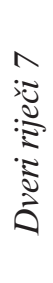 & 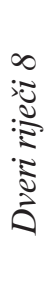 & 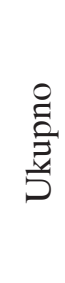 \\
\hline Majka & 17 & 21 & 10 & 16 & 10 & 23 & 19 & 17 & 14 & 15 & 10 & 12 & 184 \\
\hline Otac & 10 & 13 & 10 & 9 & 6 & 18 & 14 & 12 & 11 & 16 & 10 & 18 & 147 \\
\hline
\end{tabular}




\begin{tabular}{|c|c|c|c|c|c|c|c|c|c|c|c|c|c|}
\hline $\begin{array}{c}\text { Dijete } \\
\text { (muško) }\end{array}$ & 11 & 21 & 10 & 10 & 8 & 17 & 9 & 9 & 7 & 10 & 11 & 12 & 135 \\
\hline $\begin{array}{c}\text { Dijete } \\
\text { (žensko) }\end{array}$ & 3 & 4 & 7 & 3 & 5 & 8 & 3 & 8 & 3 & 7 & 7 & 15 & 73 \\
\hline Brat & 2 & 6 & 7 & 2 & 6 & 5 & 11 & - & 3 & 1 & 1 & 4 & 48 \\
\hline Baka & 11 & 4 & 1 & 2 & 2 & 5 & 1 & 2 & 6 & 6 & 2 & 5 & 47 \\
\hline Djed & 4 & 2 & 1 & 1 & 2 & 3 & 4 & 3 & 4 & 4 & 2 & 3 & 33 \\
\hline Sestra & 1 & 9 & 3 & 3 & 1 & 6 & 2 & 3 & 3 & - & 1 & 1 & 33 \\
\hline Ujak & 1 & - & 1 & 1 & 1 & 4 & - & 2 & - & 1 & - & 1 & 12 \\
\hline Stric i strina & - & - & - & - & - & 5 & - & 1 & - & 1 & - & - & 7 \\
\hline Tetka & 1 & - & 1 & - & - & - & - & 1 & - & 1 & - & - & 4 \\
\hline $\begin{array}{c}\text { Sestrična i } \\
\text { bratić }\end{array}$ & - & - & 1 & 1 & - & 1 & - & - & - & - & - & - & 3 \\
\hline \multicolumn{13}{|c|}{ Sveukupno pojavljivanje čimbenika obitelji kao motiva u tekstovima } & 726 \\
\hline
\end{tabular}

\section{Rasprava}

Slijede naslovi tekstova kojima se dokumentiraju kvantitativni pokazatelji. Motiv obitelji i njezinih čimbenika u naslovima cjelina i naslovima tekstova: Obitelj; Majka; Mamina maza; S ljubavlju iščekivanom djetetu; Breze moga oca; Otac; Sestre; Pobuna roditelja; Baka i bašča; Ja u obitelji, obitelj u meni (naslov cjeline); Kad moja majka govori; Udarila me ona, moja majka; Ive sestru Draginju spašava; Djed je pričao ocu, а ја с́и sinu (naslov cjeline); Obitelj i sjećanja (naslov cjeline); Kako sam postao brat; Hvaljen Isus, moja stara bako; Mama moja mamasta; Stric-vujc; Babina Bilka; Otac i ja kosimo travu; Jurin djed po ocu dobiva napadaj pisanja; Moj tata spava s anđelima; Rođeni, hajde s dejkom da bacimo mreže; Baka i Bokelji; Priča za roditelje; Viški djed — bez unuka; Radosti obiteljskog prijevoza; Isus i moja mat $\mathrm{i} \mathrm{dr}$.

Utvrdili smo da se pojedini naslovi ponavljaju u čitankama različitih izdavača. To su: Zastidio se majke; Tata nema vremena; Djedovo slovo; Smrt moje bake; Djedove obrve; Moj did; Moj djed; U ljetne večeri postaju mreže moga djeda srebrne. Djelo koje sadrže čitanke sva tri analizirana izdavača je pjesma Josipa Pupačića Tri moja brata.

Sljedeći su primjeri ilustracije o sadržajima života u različito strukturiranim obiteljima. Nuklearnu obitelj pronalazimo u djelu Lažeš, Melita: »U obitelji inženjera Kosića i njegove supruge žive sin Nenad i kći Melita «(Kušan prema Babić et al., 2005c, 28). Život u proširenoj obitelji vidljiv je u djelu Ne dao Bog većeg zla: »Obitelj Ančić prosječna je onodobna obitelj koju osim Siniše čine i roditelji 
Branko i Nevenka, sestra Biba, baka Milica te ujak Emil« (Tribuson prema Šojat, 2014c, 96).

Primjer nepotpune obitelji vidljiv je u ulomku iz romana Kroz pustinju i prašinu, u kojem čitatelj upoznaje dvije obitelji u kojima nedostaju majke: »Gospodin Rawlison, jedan od ravnatelja Kompanije Sueskoga kanala, i Wladyslaw Tarkowski, inženjer iste kompanije... bijahu udovci. Gospođa Tarkowska, rođena Francuskinja, umrla je pri Stasiovu rođenju... a Nellina je majka umrla od sušice u Heluanu « (Sienkiewicz prema Šojat, 2013, 10). U tekstu Ljubav na prvi pogled nalazi se primjer nepotpune obitelji bez otca. Djevojčica Dubravka nema u obitelji otca jer je u zatvoru: »Njena mama mnogo radi i ima velike podočnjake, Dubravkin tata ne živi s njima, on je u gradu Lepoglava (Gavran prema Bežen i Jambrec, 2009a, 12). Samo se u dva slučaja opisuje život s maćehom: »Dagmar (Keti) seli k bratiću Zlatku jer joj je tata s maćehom iznenada otputovao u Australiju «(Storić prema Šojat, 2014b, 130). U čitankama se mogu pronaći i primjeri adoptirane obitelji, iako su vrlo rijetko spomenuti u tekstovima. U ulomku djela Ann od Zelenih zabata: »Ann je znatiželjna i vedra djevojčica iz sirotišta koju su usvojili Marilla i Matthew « (Maude Montgomery prema Babić et al., 2005c, 35). Primjer zapuštene obitelji opisan je u tekstu Učiteljica i učenik: »Učiteljica trećega razreda upisala je da je 'majčina smrt ostavila na Teddyju dubok trag... On pokušava i trudi se, ali ni otac ne pokazuje za nj dovoljno interesa, pa zaključujem da će mu život kod kuće sasvim sigurno nauditi, ukoliko se ne poduzmu neki hitni koraci'« (nepoznat autor prema Šojat, 2014a, 94).

Razlike u sadržajima tekstova za 5. i 6. razred u odnosu na 7. i 8. razred su kvalitativne prirode, a očituju se u razlozima zbog kojih dolazi do razdvajanja obitelji. U tekstovima namijenjenih polaznicima 5. i 6. razreda uopće nije spomenut razlog nastanka nepotpune obitelji. Ako je istaknut, onda je uzrok smrt roditelja, a na takav događaj nije moguće utjecati. U tekstovima namijenjenih 7. i 8. razredu razlozi nastanka nepotpune obitelji najčešće su subjektivnoga karaktera, a očituju se u razvodima roditelja.

\section{Zaključak}

Kvaliteta obiteljskoga života i vrijednosti koje se njeguju unutar obiteljske zajednice utječu na budući život svakoga njezina člana, a posebice djece. Na kvalitetu djetetova odrastanja utječe i obiteljska struktura. Život u potpunoj obitelji djetetu pruža stabilnost. Ono odrasta uz ljubav i brigu oba roditelja i stalno je u kontaktu s njima. U nepotpunoj obitelji nedostatak jednoga roditelja odražava se na zadovoljstvo svih članova obitelji. Djeca su nesretna jer im nedostaje roditelj, a roditeljima nije lako jer moraju na sebe preuzeti uloge roditelja koji nedostaje.

Možemo zaključiti da tekstovi u čitankama hrvatskoga jezika od 5. do 8 . razreda osnovne škole oslikavaju realnu situaciju hrvatskoga društva, u kojem prevladava nuklearna obitelj. Vrijednosti koje su najčešće spominjane uz članove obitelji možemo povezati s određenim spolom. Osjećaj sigurnosti pripisan je majkama i bakama, a hrabrost i osjećajnost očevima i muškoj djeci. Muški su 
likovi u tekstovima prikazani kako plaču, pa je time "razbijen" stereotip, a djeci je prenesena poruka da ne trebaju prikrivati svoje osjećaje. Velika raznolikost tekstova i različitost čitanki omogućuju učiteljima slobodu u odabiru odgojnih vrijednosti koje žele promicati u svojoj nastavi.

Pozitivna je činjenica da su unutar sadržaja čitanki i primjeri nepotpunih obitelji. Čitanke sadrže tekstove u kojima su razmatrani različiti životni problemi, poput smrti roditelja, razvoda roditelja, napuštenoga dijete, smrti braće, sestara, baki ili djedova, nasilja u obitelji i dr. Učenicima nije prikazan savršen svijet $u$ kojem ne postoje prepreke, nego realnost sa svim svojim lijepim ali i ružnim stranama. U tekstovima su prikazani problemi, ali često puta i rješenja. Kada se rješenje ne može pronaći u tekstu, tijekom provođenja odgojno-obrazovnoga procesa otvoren je prostor i mogućnost za raspravu i rad na formiranju odgojnoga i vrijednosnoga sustava učenika.

\section{Literatura}

Aniger, Natalie (2013). The Changing American Family. U: New York Times (23. studenoga). URL: https://www.nytimes.com/2013/11/26/health/families.html (08.03.2020.)

Aračić, Pero; Nikodem, Krunoslav (2000). Važnost braka i obitelji u hrvatskom društvu. Bogoslovska smotra, 70(2), 291-311.

Babić, Nada, Đurić, Ivan, Golem, Dinka, Jelčić, Dunja (2005d). Dveri riječi 8: Hrvatska čitanka za 8. razred osnovne škole. Zagreb: Profil.

Babić, Nada, Golem, Dinka, Jelčić, Dunja (2005a). Dveri riječi 5: Hrvatska čitanka za peti razred osnovne škole. Zagreb: Profil.

Babić, Nada, Golem, Dinka, Jelčić, Dunja (2005b). Dveri riječi 6: Hrvatska čitanka za šesti razred osnovne škole. Zagreb: Profil.

Babić, Nada, Golem, Dinka, Jelčić, Dunja (2005c). Dveri riječi 7: Hrvatska čitanka za 7. razred osnovne škole. Zagreb: Profil.

Balaband, Ana (1994). Naša obitelj danas. Revija za socijalnu politiku, 1(4), 413-416.

Benvin, Anton (1972). Obitelj kroz povijest. Bogoslovska smotra, 42(1), 35-51.

Bezić, Živan (1990). Biti čovjek! Ali kako? Đakovo: Biskupski ordinarijat Đakovo.

Bežen, Ante; Jambrec, Olga (2009a). Hrvatska čitanka za V. razred osnovne škole. Zagreb: Naklada Ljevak.

Bežen, Ante; Jambrec, Olga (2009b). Hrvatska čitanka za VI. razred osnovne škole. Zagreb: Naklada Ljevak.

Bežen, Ante; Jambrec, Olga (2009c). Hrvatska čitanka za VII. razred osnovne škole. Zagreb: Naklada Ljevak.

Bežen, Ante; Jambrec, Olga (2009d). Hrvatska čitanka za VIII. razred osnovne škole. Zagreb: Naklada Ljevak.

Božić Lenard, Dragana; Lenard, Ivan (2018). Analiza odgojnih vrijednosti u časopisu za djecu i mladež Milodarke. Anafora, 5(2), 295-313.

Čondić, Alojzije (2009). Život u slobodnim vezama i ženidba na pokus — kršćani u gradskim ženidbama. Diaconvensia, 15(2), 7-36.

Ferić, Ivana (2009). Vrijednosti i vrijednosni sustavi: Psihologijski pristup. Zagreb: Alineja.

Gjergji, Lush (1982). Obitelj i brak — mjesto autentičnog susreta osoba. Obnovljeni Život, 37(4), 320-336.

Herceg, Nevenko (2013). Okoliš i održivi razvoj. Zagreb: Synopsis. 
Hoblaj, Alojzije (2005). Vrijednosno usmjereni odgoj u vrijednosno usmjerenoj školi. Filozofska istraživanja, 25(2), 389-411.

Janković, Josip (2008). Obitelj u fokusu. Zagreb: Et cetera.

Juul, Jesper (1995). Razgovori s obiteljima. Zagreb: NIP Alinea.

Koračević, Karlo (1999). Novije promjene u življenju i shvaćanju braka i obitelji. Bogoslovska smotra, 69(2-3), 271-283.

Lukaš, Mirko (2010). Obiteljski odgoj u Hrvatskoj — razvoj ideja od 1850. do 1918. godine, Rijeka: Hrvatsko futurološko društvo.

Maleš, Dubravka (2012). Obitelj i obiteljski odgoj u suvremenim uvjetima. Dijete, vrtić, obitelj, 18(67), 13-15.

Mijatović, Antun (1995). Obitelj i poremećaji socijalnog konteksta. Društvena istraživanja, $4(4-5), 465-485$.

Miliša, Zlatko (2013). Novi udar na obitelj. U: Dnevno (7. lipnja). URL: https://m.dnevno. hr/kolumnisti/novi-udar-na-obitelj-88643/ (20.2.2020).

Miliša, Zlatko (2014). Šok današnjice. Osijek: Filozofski fakultet.

Miliša, Zlatko; Bagarić, Miroslav (2012). Stilovi ponašanja i vrijednosne orijentacije. MediAnali, 6(12), 68-104.

Mlinarević, Vesnica (2014). Vrijednosni sustav učitelja — determinanta kulture škole. U: Anđelka Peko et al., Kulturom nastave ( $p$ ) o učeniku (str.123 - 172). Osijek: Sveučilište Josipa Jurja Strossmayera.

Mrnjaus, Kornelija (2008). Pedagoška promišljanja o vrijednostima. Rijeka: Filozofski fakultet Sveučilišta u Rijeci.

Munjiza, Emerik; Lukaš, Mirko; Peko, Anđelka (2007). Odgojne vrijednosti u hrvatskoj usmenoj književnosti. U: Ernest Barić, Dragica Dragun, Dragica Haramija i Ana Pinarić (ur.), Zlatni danci 8: Mitovi i legende (str. 207-220). Osijek: Filozofski fakultet.

Mušanović, Marko; Lukaš, Mirko (2011). Osnove pedagogije. Rijeka: Hrvatsko futurološko društvo.

Nimac, Dragan (2010). (Ne)mogućnosti tradicijske obitelji u suvremenom društvu. $O b$ novljeni Život, 65(1), 23-35.

OECD (2011). Organisation for Economic Co-operation and Development, Families are changing. URL: https://www.oecd.org/els/soc/47701118.pdf. (09.03.2020.)

Pew Research Center (2015). Parenting in America: Outlook, worries, aspirations are strongly linked to financial situation. U: Pew Research Center (17. prosinca). URL: https://www.pewsocialtrends.org/2015/12/17/parenting-in-america/ (03.12.2020.)

Piršl, Elvi; Vican, Dijana (2004). Europske demokratske vrijednosti i regionalizam. Pedagogijska istraživanja, (1)1, str. 89-103.

Raboteg-Šarić, Zora (2001). Komunikacija između djece i roditelja. U: Stjepan Baloban (ur.), Hrvatska obitelj na prekretnici (str. 221-253). Zagreb: Glas Koncila.

Rafajac, Branko (1991). Odgoj kao razvoj autonomne vrijednosne svijesti. Rijeka: Pedagoško društvo.

Rakić, Vini; Vukušić, Svjetlana (2010). Odgoj i obrazovanje za vrijednosti. Društvena istraživanja, 19(4-5), 771-795.

Rosić, Vladimir; Zloković, Jasminka (2002). Prilozi obiteljskoj pedagogiji. Rijeka: Graftrade.

Stacey, Judith (1996). In the Name of the Family. Boston: Beacon Press.

Šojat, Anita (2013). Snaga riječi 6: Hrvatska čitanka za šesti razred osnovne škole. Zagreb: Školska knjiga.

Šojat, Anita (2014a). Snaga riječi 5: Hrvatska čitanka za peti razred osnovne škole. Zagreb: Školska knjiga. 
Šojat, Anita (2014b). Snaga riječi 7: Hrvatska čitanka za sedmi razred osnovne škole. Zagreb: Školska knjiga.

Šojat, Anita (2014c). Snaga riječi 8: Hrvatska čitanka za osmi razred osnovne škole. Zagreb: Śkolska knjiga.

Švab, Alenka (2007). New ways of parenting: Fatherhood and parenthood in lesbian families. Revija za sociologiju, 38(1-2), 41-53.

Trujillo Lopez Alfonso (2003). The Family and Life in Europe. URL: http://www.vatican. va/roman_curia/pontifical_councils/family/documents/rc_pc_family_doc_20030614_ family-europe-trujillo_en.html. (25.02.2020.)

Vukasović, Ante (1999). Obitelj — vrelo i nositeljica života. Zagreb: Hrvatski katolički zbor MI.

Životić, Miladin (1986). Aksiologija. Zagreb: Naprijed.

The Factors of Family Life and the Values Promoted in Readers for Croatian Language Classes

Mirko Lukaš*, Anamarija Jurinić***

\section{Summary}

The sociological approach views the family as the primary cell of human association. Each family has its own specific structure. Modern society is acknowledged increasingly for its role in nurturing the nuclear family consisting of parents and their children. The traditional family has an extended structure consisting of parents and children and their relatives living in a shared household. Nowadays, we are encountering more and more incomplete families who are missing one parent or are families with a stepfather or stepmother. The functioning of a family is most strongly reflected in child-rearing, but also in the transfer of the value system nurtured by individual families. As a child grows and develops, it enters school trying to be an extension of this function. This is especially prevalent when the mother tongue is taught in school and in texts in which certain value categories are disseminated through school textbooks(readers). The aim of this paper is to analyze the content on the family as a literary motif in Croatian language readers for the fifth grade and up to the eighth grade of elementary school by analyzing the content, and subsequently, to determine the frequency of occurrence of family life factors that shape different structures and their representation in the texts of the readers. In the texts analyzed the structure of the nuclear family is dominant, but they also include examples of incomplete families. The family values which are promoted vary with gender, but the family as a phenomenon still does not cease to have a strong presence as well as an educational role.

Key words: educational influence; incomplete family; redefinition; free relationships; values

* Mirko Lukaš, Ph.D., Associate Professor, Department of Pedagogy, Faculty of Humanities and Social Sciences in Osijek. Address: Lorenza Jägera 9, 31000 Osijek, Croatia.

E-mail:mirkolukas64@gmail.com

** Anamarija Jurinić, mag. educ. philol. angl., Address: Pakračka 8, 32010 Vukovar, Croatia. E-mail: anamarija.jurinic@gmail.com 